症例

腹部大動脈瘤破裂後仮性動脈瘤形成の超高齢者に対し 待期手術を施行し救命した 1 例

\author{
岡山赤十字病院外科 \\ 池田英二名和清人 古谷四郎 \\ 辻尚志市原周治野上智弘
}

超高齢者腹部大動脈嘴破裂例で心不全，腎不全に陥り，患者側の意思で自然経過に委 ねた保存的治療が選択され，状態改善後に待期手術で救命した 1 例を経験した。患者は 87歳，女性で突然の腹痛をきたしショック状態で入院した．腹部大動脈瘤破裂と診断し たがショックに伴う意識障害と心不全，腎不全に陥っていた。患者側の意思で保存的治 療が選択されたが，状態が改善したため約 1 力月後に再検討し手術を施行した．後腹膜 血腫は一部吸収・縮小するも残存血腫と仮性瘤がTreitz 勒帯後方にあり，周辺の強固な 瘾着と肥厚もあり右側アプローチで留動脈直下大動脈を捕捉・遮断しえた。真性㾇部を 切開し, 瘤内より癐壁を切離しつつ大動脈を剥離し $\mathrm{Y}$ 字グラフトにより再建, 術後は合 併症なく経過した，極めて例外的とは思われるが症例によっては，待期手術による救命 の可能性があることも忘れてはならない。

索引用語：腹部大動脈瘤破裂，待期手術，超高齢者

はじめに

腹部大動脈瘤破裂は，通常緊急手術が行われるが， 成績は待期手術に比へ満足できるものではなく”，術 前状態が損なわれていれば極めて不良である21 5). 著 者らは，超高齢者腹部大動脈處破裂例で心不全，腎不 全に宿り, 患者側の意思で手術は拒否され, 保存的治 療の選択を余儀なくされたが, 状態が改善した後では 手術を希望され，待期手術にて救命した 1 例を経験し たので報告する。

\section{症例}

患 者：87歳，女性.

主 訴: ショックを伴う腹痛.

既往歴：約 8 年前に堅下部腹部大動脈瘤を指摘さ れ，高齢を理由に経過観察されていた。

現病歴: 平成12年 1 月 4 日, 突然の腹痛を発症し, ショック状態で当院循墂器内科に入院した。

入院時現症: 意識混濁し顔面荅白, 脈拍数 61 /分·微 弱, 収縮期体血圧は触診にて70 $\mathrm{mmHg}$ であった。

2003年 5 月12日受付 2003 年 7 月 8 日採用

〈所属施設住所〉

于700-8607 岡山市青江 $2-1-1$
入院時血液 - 生化学検査 : $\mathrm{RBC} 267$ 万 $/ \mathrm{mm}^{3}, \mathrm{Hgb}$ $8.4 \mathrm{~g} / \mathrm{dl}$, Hct $24.5 \%$, PLT $155,000 / \mathrm{mm}^{3}$, GOT $11 \mathrm{U} /$ l, GPT $8 \mathrm{U} / \mathrm{l}$, T-Bil 0.4mg/dl, TP $5.6 \mathrm{~g} / \mathrm{dl}$, Alb 3.0 $\mathrm{g} / \mathrm{dl}$, BUN $62.6 \mathrm{mg} / \mathrm{dl}, \mathrm{Cr} 1.7 \mathrm{mg} / \mathrm{dl}$.

入院時胸部 X 線写真：CTR 77.3\%と著明な心陰影 の㹡大と肺管血を認めた（図 1 ).

入院時腹部 CT: 複雑な形態を示す腎下部腹部大動 脈瘤と (四 $2 a$ ), 主に左側腹部を占める巨大後腹膜血 腫を認め(図 2 b)，動脈瘤破裂と診断した。

発症22時間後に当外科に紹介されたが，意識障害お よびショック状熊が持続し，既に腎不全に陥っており， 患者側の意思より緊急手術は拒否され保存的治療がな された。しかし心，督不全を含め全身状熊が徐々に改 善し, 約 1 カ月後に再検討された。

術前血液生化学検查: $\mathrm{RBC} 340$ 万 $/ \mathrm{mm}^{3}, \mathrm{Hgb} 10.6$ $\mathrm{g} / \mathrm{dl}$, Hct $31.5 \%$, PLT $256,000 / \mathrm{mm}^{3}$, GOT $27 \mathrm{U} / \mathrm{l}$, GPT 24U/1, T-Bil 0.9mg/dl, TP 5.9g/dl, Alb 3.2 $\mathrm{g} / \mathrm{dl}$, BUN $27.6 \mathrm{mg} / \mathrm{dl}, \mathrm{Cr} 1.7 \mathrm{mg} / \mathrm{dl}$.

術前胸部 X 線写真：CTR 65\%と心陰影は縮小し， 肺燓も消退して心不全は改善していた（図3).

腹部 CT：後腹膜血腫は一部吸収されて縮小し，十 二指腸水平部, 膵体尾部から結腸脾鹪曲部後方に達す 


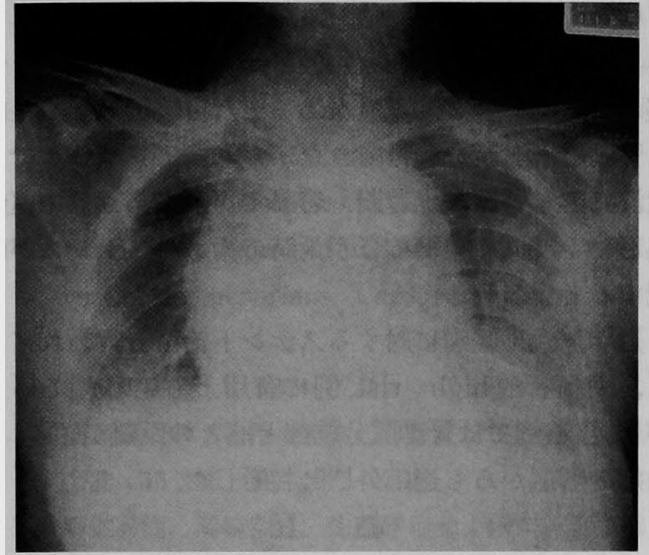

図 1 入院時胸部 X 線写真：心・縦隔陰影の著明な 拡大と肺樂血像を認める。
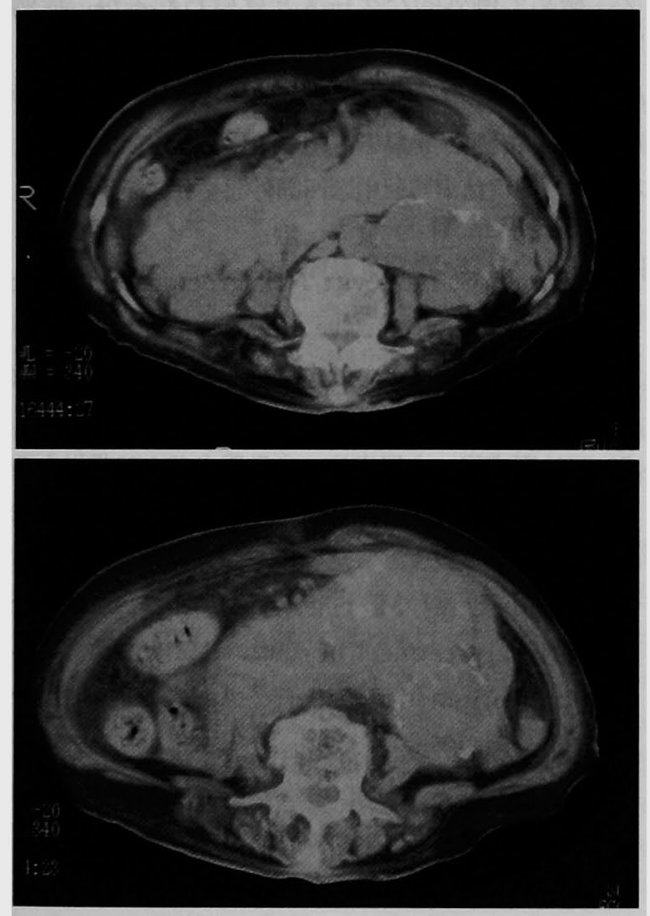

図 2 入院時腹部 CT：a）留下部毫状瘤が左側腹部 にみられる， b) 左側腹部を中心に広範に出血を認 める.

$\frac{a}{b}$

\section{る仮性瘤形成を認めた（図 4 a， b ).} 心機能, 腎機能, 意識レベルなどの改善を認め, 今 回は手術を希望され，破裂後42日目に手術を施行した。 手術：腹部正中切開施行, 残存する血腫と仮性瘤が

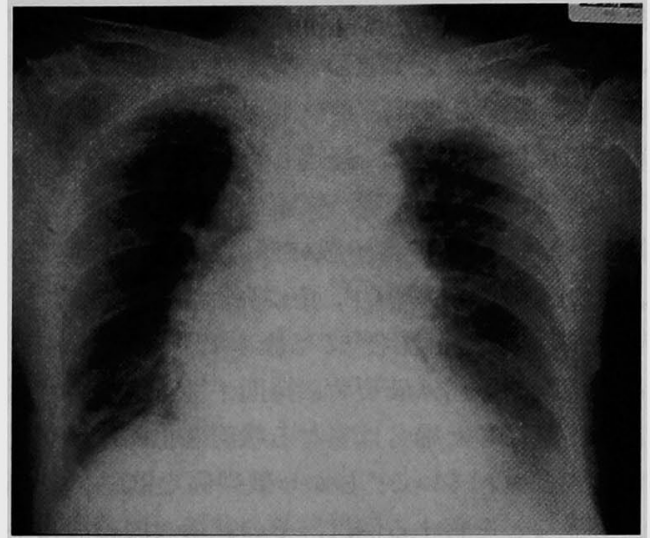

图 3 術前胸部 X 線写真：心・縦隔陰影は縮小し, 肺 敕血像も消失している。
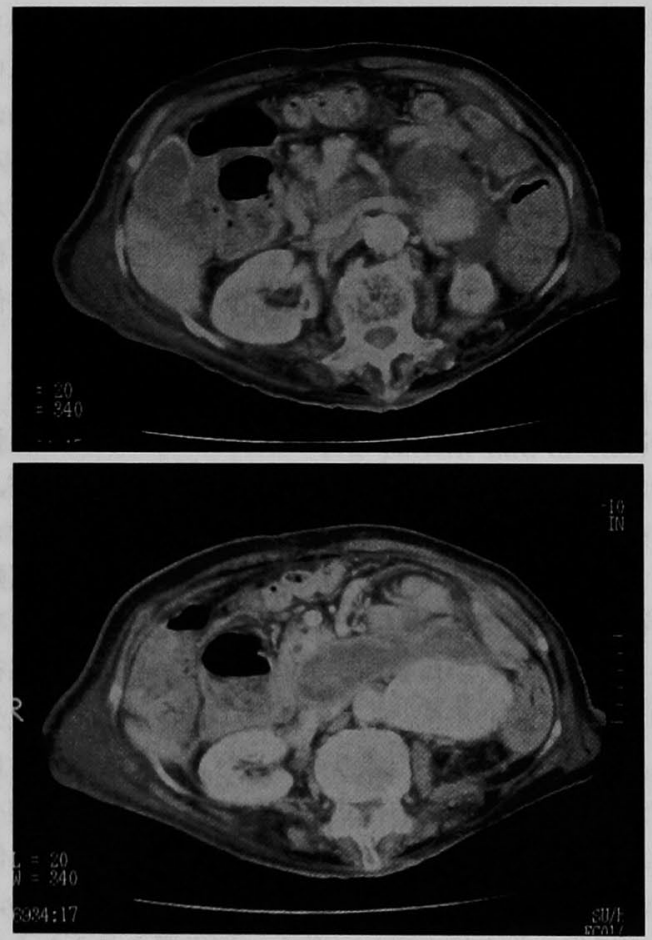

図 4 腹部 CT：a）血腫は吸収·縮小し左上腹部に仮 性瘤の天蓋部を認める。, b ) 十二指腸水平部の軽度 拡張を認める。

$\frac{\mathrm{a}}{\mathrm{b}}$

Treitz $z$ 靯帯の後方にあり, 周辺は強固な痛着と肥厚の ため，左側アプローチは不可能と判断した．督動脈上 ての大動脈遮断を想定し，十二指腸を Kocher 授動術 にて剝離，右側アプローチにより腎動脈直下大動脈を 
捕捉・遮断した，瘤の isolation を得て真性瘤部を切開 し, 瘤内より瘤壁を切離しつつ大動脈を剥離して遮断 部に達し, 通常の $\mathrm{Y}$ 字グラフトによる大動脈再建術を 施行, 術後は合併症なく経過した.

\section{考 察}

腹部大動脈瘤破裂は一般に緊急手術の対象である

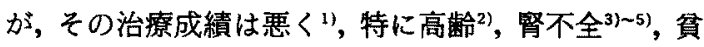
血 ${ }^{56)}$ やショック持続(例57)では極めて不良である.その ため腹部大動脈瘤は破裂前に待期手術を行うのが原則 であり，破裂した場合は更なる状態悪化前に早急に手 術すべきとされている。しかし破裂例で重篤な心，脳， 腎合併症などを有する例は，その悲惨な成績故に手術 適応から外れるという意見がある288. また重篤な合併 症を有し全身状態が不良な破裂例では，第一に保存的 治療を優先し，全身状態の改善や後腹膜血腫が吸収・ 縮小された後手術を行うという意見もあるが，散見さ れるのみであり ${ }^{199}$, 実際の臨床に則したものとは思い 難い. Chronic contained rupture のように自然経過か ら結果的に慢性化し仮性動脈瘤となった例も存在する が，この場合でも再破裂を念頭に可及的早期の手術が 勧められている(0). 自験例は患者側の意思で緊急手術 でなく保存的治療が選択され，状態改善後に待期手術 を行ったものである.

超高齢者大動脈嘴破裂例の緊急手術は手術死亡が 9 〜 $20 \%$, 病院死亡が $43 \sim 65 \%$ と極めて不良な成績が報 告されている2)8 . 比較的良好な成續の報告もあるが, その多くは手術開始時の血圧，尿量が正常に維持でき ている例を対象としたものでるる゙．自験例は超高齢 者破裂例で心不全，無尿を伴い前述の risk factor を有 しており，厳しい周術期が予測された。しかし，保存 的治療後には心不全, 堅不全などの risk factor が減少 し，全身の予備力が高まり手術を行えたことが救命に 繁がったものと考える．更に後腹膜血腫も吸収・縮小 したため手術時の解剖学的位置関係把握にも有利に偟 き，破裂孔も仮性動脈瘤を形成して止血を得たため， 手術操作の安全性も増し，救命に好影響を与えたもの と思われる。

手術に際しては，残存する血腫と仮性㿔の物理的障 害や強固な瘜着と肥厚のため, 通常の左側アプローチ は困難と判断し, 腎動脈上大動脈遮断も想定して右側 からアプローチした．腎動脈上遮断については良好な 成績が報告されておりい，特に破裂時には腎動脈下遮 断に拘り大動脈の剥離に手間取るよりは，腎動脈上遮 断で迅速にショックから離脱することが重要といわれ
ている ${ }^{12)}$. 胸部下行大動脈遮断の有用性も報告されて いるが'洞開胸と腹腔内全臓器への血行遮断で, 上り侵 襲が堌すため否定的意見もある ${ }^{122}$. 自験例では結果的 に腎動脈下遮断を施行できたが，右側アプローチでは 状況に応じ腎動脈上遮断も容易に可能であり，中枢側 処理に手間取る症例では手術時の術者のストレスが軽 減すると思われる。

近年, 大動脈瘤に対するステント治療も行われてお り，高齢者や high risk例に有用ともいわれている が (14), 自験例では腎動脈分枝部と瘤との距離が短く,ま た瘤の形態からも適応外 ${ }^{15)}$ と判断した。

\section{結 語}

1. 腹部大動脈瘤破裂後に仮性動脈瘤を形成した超 高齢者に対して, 待期手術を余儀なく施行し救命に成 功した.

2. 極めて例外的なケースとは思われるが, 症例に より救命の可能性があることを改めて教えられた。

3. 強固な觝着と肥厚のため, 仮性瘤形成の反対側 に相当する右側からのアプローチが有用であった.

本論文の要旨は第75回中国四国外科学会にて発表した，

\section{文献}

1) Johnson G, McDevitt $\mathrm{NB}$, Proctor HJ, et al : Emergent or elective operation for symptomatic abdominal aortic aneurysm. Arch Surg $115: 51-53,1980$

2）日比野成俊，土屋幸治，中島雅人他：80歳以上の 超高齢者の腹部大動脈㾇に対する外科治療の検 討．日心臓血管外会誌 $31: 321-324 ， 2002$

3) Alonso-Perez $M$, Segura RJ, Pita $S$, et al: Surgical treatment of ruptured abdominal aortic aneurysm in the elderly. Ann Vasc Surg 13: 592-598, 1999

4) Halpern VJ, Kline RG, D'Angelo AJ, et al : Factors that affect the survival rate of patient with ruptured abdominal aortic aneurysm. J Vasc Surg $26: 929-948,1997$

5）前田光徳，小長井直樹，矢野浩巳 他：破裂性腹部 大動脈瘤の手術成綞を左右する因子の検討一とく に新しい概念であるショック時間指数を中心に 一。日心臟血管外会誌 $31: 24-28,2002$

6) Johansen $K$, Kohler TR, Nicholls $S C$, et al: Ruptured abdominal aortic aneurysms: The Harborview experience. J Vasc Surg $13: 240-$ 247, 1991 
7) Rosenthal D, Mckinsey JF, Erdoes LS, et al : Ruptured abdominal aortic aneurysm : Factors affecting survival and long-term results. J Vasc Surg 1:53-55, 1992

8) Falk V, Vettelschoss M, Walther B, et al: Surgical treatment of abdominal aortic aneurysm of octogenarians. Cardiovasc Surg 4:727 $-731,1996$

9）富川正樹，上山武史，笠島 学他：破裂性腹部大 動脈瘁に対する待機手術の有用性. 日心搭血管外 会誌 $15: 96-97,1985$

10）野並苊樹, 岡崎桼長, 佐藤幸治他：巨大後腹膜腫 瘍像を呈した慢性腹部大動脈溜破裂の 1 手術例. 日心臟血管外会誌 $23 ： 296-299 ， 1994$

11) Crawford ES: Ruptured abdominal aortic aneurysm : An editorial. J V'asc Surg 13:348-
350,1991

12）羽净影, 山里有男, 山田知行：破裂性腹部大動 脈嘴手術経験の検討. 日心蔵血管外会誌 $31: 258$ $-261,2002$

13）末田泰二郎，渡橋和政，吞村孝之他：破裂性腹部 大動脈瘤の外科治療における左開胸併用法の有用

性. 日心搰血管外会誌 $23: 88-91,1994$

14) Chuter TA, Reilly LM, Faruqi RM, et al : Endovascular aneurysm repair in high-risk patients. J Vasc Surg $31: 122-133,2000$

15) Treiman GS, Lawrence PF, Edwards WH Jr, et al: An assessment of the current applicability of the EVT endovascular graft for treatment of patients with an infrarenal abdominal aortic aneurysm. J Vasc Surg $30: 68-75,1999$

\title{
SUCCESSFUL DELAYED OPERATION ON A SUPER-OLD PATIENT WITH PSEUDOANEURYSM DEVELOPING AFTER RUPTURE OF ABDOMINAL AORTIC ANEURYSM
}

\author{
Eiji IKEDA, Sugato NAWA, Shirou FURUTANI, \\ Hisashi TSUJI, Shuji ICHIHARA and Tomohiro NOGAMI \\ Division of Surgery, Okayama Red Cross General Hospital
}

An 87-year-old woman admitted to the hospital because of the sudden onset of abdominal pain with shock was diagnosed with having rupture of an abdominal aortic aneurysm. The patient had already presented not only cardiac but also renal failure with consciousness disturbance. As the informed consent for the surgical intervention was not obtained, conservative therapy was commenced. After one month with medical treatment, the patient survived the deteriorated renal, respiratory and circulatory conditions, with much improvements, and desired for corrective surgery. At operation, the right-side approach was used since the development of pseudoaneurysm was noted in the left upper retroperitoneum on CT and the left-side approach was considered not feasible because of firm adhesion and severe fibrous thickening around the ligament. Placing a cross clamp with success on the infrarenal abdominal aorta from the right side, the aneurysm was incised, and dissection of the aneurysm from the surrounding tissue was carried out intraluminally as well as extraluminally, facilitating the access of the anastomotic site of the aorta. The abdominal aorta was reconstructed using a Y-shaped vascular graft, and the postoperative course was eventually smooth. We do not think that present strategy is genarally feasible, and there is the possibility of the survival in such cases as ours. 